\title{
Microsatellite Analysis of the Parental Contribution of Piaractus mesopotamicus to the Production of Offspring in the Semi-natural System of Reproduction
}

\author{
Jayme Aparecido Povh ${ }^{1 *}$, Ricardo Pereira Ribeiro ${ }^{2}$, Rodolfo Nadez Sirol ${ }^{3}$, Danilo Pedro \\ Streit Jr. ${ }^{4}$, Heden Luiz Marques Moreira ${ }^{5}$, Frank Siewerdt ${ }^{6}$, Nelson Mauricio Lopera- \\ Barrero $^{2}$, Claudete Aparecida Mangolin ${ }^{7}$ and Lauro Vargas ${ }^{2}$ \\ ${ }^{1}$ Instituto de Ciências Agrárias e Tecnologias; Universidade Federal do Mato Grosso; Rod. MT-270, km 06; \\ 78735-901; Rondonópolis - MT - Brasil. ${ }^{2}$ Departamento de Ciência Animal; Universidade Estadual de Maringá; \\ 87020-900; Maringá - PR - Brasil. ${ }^{3}$ Duke Energy International Geração Paranapanema; 8970-000; Chavantes - SP \\ - Brasil. ${ }^{4}$ Departamento de Ciência Animal; Universidade Federal do Rio Grande do Sul; 91540-000; Porto Alegre \\ - RS - Brasil. ${ }^{5}$ Departamento de Zoologia e Genética; Universidade Federal de Pelotas; C. P.: 354; 96010-900; \\ Pelotas - RS - Brasil. ${ }^{6}$ Department of Animal and Avian Sciences; University of Maryland; College Park; MD \\ 20742-2311; USA. ${ }^{7}$ Departamento de Biologia Celular e Genética; Universidade Estadual de Maringá; 87020-900; \\ Maringá - PR - Brasil
}

\begin{abstract}
The objective of this study was to evaluate the genetic diversity and the parental contribution of Piaractus mesopotamicus in the production of offspring in the semi-natural system of reproduction. Twenty parental fishes (eleven males and nine females) and the total of 100 larvae were evaluated by microsatellite marker. The parents and offspring had thirty-one alleles and heterozygosity of 0.550 and 0.563 , respectively. The females were fertilised by two up to six males while the males fertilised three up to five females. The contribution of the females and males to the offspring were 66.6 and 58\%, respectively. Such results indicated no loss in the genetic variability in the offspring, and the parents had multiple paternity and reasonable contribution to the offspring production.
\end{abstract}

Key words: Genetic variability, Stock enhancement programme, Reproductive management.

\section{INTRODUCTION}

The fishing activity in the Brazilian rivers has been reduced to critical levels. In this context, the pacu (Piaractus mesopotamicus) is becoming rare in the Parapanema River (Brito et al., 2003) due to the environmental pollution, soil erosion, overfishing, the constant presence of power plants (dams), and the inappropriate establishment of other species (Agostinho et al., 2003; Tejerina-
Garro et al., 2005; Hatanaka et al., 2006). In order to overcome such difficulties, many hatchery stations have been releasing the fishes for enhancing the natural populations and reducing the adverse effects of small stocks in the freshwater ecosystems. In this a way, more than 9.8 million of juveniles have been released into the rivers of the Paraná State by the fish-stock enhancement programmes developed by the Secretaria de Estado da Agricultura e Abastecimento whose aim

*Author for correspondence: jayme.peixegen@gmail.com 
is to release 20 million of juveniles. Particularly, 610,000 juveniles of $P$. mesopotamicus, Prochilodus lineatus, and Leporinus elongatus (Agência Estadual de Notícias, 2007) have already been released.

Although such programmes have been releasing the fishes for more than three decades (Agostinho et al., 2005) they have also been questioned because the lost the genetic diversity induce adverse effects, which affect significantly the ichthyofauna and to reduce the capacity of environmental adaptation juveniles released into the rivers. The most important management practice in stock enhancement programmes is monitoring the genetic diversity of the offspring (Sirol and Britto, 2006). The molecular markers are the most important method to achieve such purposes (Barroso et al., 2005; Liu et al., 2005; Ortega-Villaizán Romo et al., 2006; Ramella et al., 2006; Sønstebø et al., 2007).

The objective of the present study was to evaluate the genetic diversity and parental contribution of Piaractus mesopotamicus in the production of offspring in the semi-natural system of reproduction.

\section{MATERIAL AND METHODS}

\section{Fish sampling}

Eleven males and nine females of $P$. mesopotamicus from the Aquaculture Research Centre at Duke Energy Station $\left(22^{\circ} 54^{\prime} \mathrm{SL}\right.$ and $50^{\circ} 00^{\prime}$ WL), in Salto Grande, São Paulo, Brazil, were sampled from two hundred and fifty 4-yearold broodstock whose parents were previously collected in the Paraná River, a tributary of the Paranapanema River.

\section{Reproduction system}

The semi-natural system of the reproduction was based on the system described by Zaniboni-Filho and Nuñer (2004). In the present case, the extract of carp pituitary at $2.5 \mathrm{mg} \mathrm{kg}^{-1}$ body weight was injected into the males. The females were induced to spawn by partitioned doses at $5.5 \mathrm{mg} \mathrm{kg}^{-1}$ body weight: $10 \%$ in the first and $90 \%$ in the second injection applied 24-h later. After the hormonal induction, parental fish were placed into a circular tank with $5.1 \mathrm{~m}$ of radius, $1.8 \mathrm{~m}$ deep, and continuous water flow of $131 \mathrm{~L} \mathrm{~s}^{-1}$. A pipe with 6" in diameter and a gate valve were used to permit the water flow of $7 \mathrm{~L} \mathrm{~s}^{-1}$ from the central part of the tank while the eggs were carried towards the collector. A conical incubator with the capacity of $200 \mathrm{~L}$ was set $2 \mathrm{~m}$ below the circular tank for collecting the eggs for further hatching under the laboratory conditions. The eggs were collected at one-hour intervals for six times. The progeny were randomly sampled one day after hatching by collecting 100 fish larvae which were stored into plastic tubes with $1.5 \mathrm{~mL}$ of ethanol (70\%) for posterior DNA extraction and amplification.

\section{Semen analyses}

Progressive motility were scored from 0 to $100 \%$ according to Billard et al. (1995) by diluting a drop of semen $(0.02 \mathrm{~mL})$ into eight drops of water $(0.16 \mathrm{~mL})$ on a glass slide coated with a cover slip for counting under optical microscope. The spermatozoa concentration was evaluated by the Neubauer chamber which was filled with semen diluted into 1:2000 saline formaldehyde. The counting was carried out on five squares of $1 \mathrm{~mm}^{-2}$ by using an optical microscope and each record was multiplied by the chamber height and dilution index. The spermatozoa morphology was evaluated by counting 100 spermatozoa per male after staining them with Bengal Rose (Streit Jr. et al., 2004). The primary (tail bent, coiled bent, short-tail, abaxial bent, giant head, small head, and twin tail) and secondary (shoe-hook tail, headless, tailless, and immature spermatozoa) abnormalities were counted by using a phase contrast microscope with lens of 40X.

\section{DNA extraction}

DNA was isolated from 100 fish larvae sampled at random and from $0.5 \mathrm{~cm}^{-2}$ taken from fin-clippings of twenty parental fish. The DNA extraction was based on the methods described by Aljanabi and Martinez (1997). In the present case, the samples were treated with $550 \mu \mathrm{L}$ lyse buffer $(50 \mathrm{mM}$ Tris$\mathrm{HCl}, 50 \mathrm{mM}$ EDTA, $100 \mathrm{mM} \mathrm{NaCl}$, and 1\% SDS$20 \%)$ and $7 \mu \mathrm{L}$ proteinase $\mathrm{K}(200 \mu \mathrm{g} / \mathrm{mL})$ per sample and incubated at $50^{\circ} \mathrm{C}$ overnight. Thereafter, the purification was carried out in 400 $\mu \mathrm{L} \mathrm{NaCl}(5 \mathrm{M})$, centrifuged at $14,000 \mathrm{rpm}$ for 10 minutes, and precipitated in $400 \mu \mathrm{L}$ of freezing ethanol. This DNA were rinsed by ethanol (70\%), re-suspended in TE $(10 \mathrm{mM}$ Tris and $1 \mathrm{mM}$ EDTA) and treated with $6 \mu \mathrm{L}$ RNAse $(30 \mu \mathrm{g} / \mathrm{mL})$ at $38^{\circ} \mathrm{C}$ for $1 \mathrm{~h}$. The DNA was quantified by comparing the concentrations of phage $\lambda$ DNA in agarose gel (1\%), and stained with ethydium 
bromide $(20 \mathrm{~g} / 100 \mathrm{~mL})$. The electrophoresis was carried out in TAE 1X (40 mM Tris-acetate and 1 mM EDTA) buffer at 70 volts for $1 \mathrm{~h}$ and the profile was visualised under the UV-radiation and photographed with the Kodak EDAS-290 (Kodak 1D Image analysis 3.5).

\section{Microsatellite analysis}

DNA was amplified to $20 \mu \mathrm{L}$ by using the buffer $1 \mathrm{X}$ Tris- $\mathrm{KCl}, 2.0 \mathrm{mM} \mathrm{MgCl}_{2}, 0.8 \mu \mathrm{M}$ from each primer (forward and reverse), $0.2 \mathrm{mM} \mathrm{dNTP}$, one unit of Platinum Taq DNA polymerase, $10 \mathrm{ng}$ DNA larvae, and 20 ng DNA parental. The following primers (Calcagnotto et al. 2001) were used: Pme2 (AF362445), Pme4 (AF362446), Pme5 (AF362447), Pme14 (AF362448), Pme20 (AF362449), Pme21 (AF362450), Pme28 (AF362451) and Pme32 (AF362452). The PCR reactions were performed with Eppendorf Mastercycler Gradient thermocycler under the following conditions: initial denaturation for $4 \mathrm{~min}$ at $94^{\circ} \mathrm{C}, 30$ cycles of $30 \mathrm{~s}$ denaturation at $94^{\circ} \mathrm{C}, 30$ $\mathrm{s}$ at a primer-specific annealing temperature (Pme2: $60^{\circ} \mathrm{C}$, Pme4: $60^{\circ} \mathrm{C}$, Pme5: $60^{\circ} \mathrm{C}$, Pme14: $62^{\circ} \mathrm{C}$, Pme20: $58^{\circ} \mathrm{C}$, Pme21: $68^{\circ} \mathrm{C}$, Pme28: $60^{\circ} \mathrm{C}$, Pme32: $66^{\circ} \mathrm{C}$ ), $1 \mathrm{~min}$ extension at $72^{\circ} \mathrm{C}$ followed by a final extension at $72^{\circ} \mathrm{C}$ for $10 \mathrm{~min}$.

The amplified samples were submitted to gel electrophoresis by using $10 \%$ polyacrylamide (acrylamide : bisacrylamide - $29: 1$ ), denaturant (6 $\mathrm{M}$ urea), and $1 \mathrm{X}$ TBE buffer $(90 \mathrm{mM}$ TrisBorate and $2 \mathrm{mM}$ EDTA) using $50 \mathrm{~mA}$ for 7 hours. The alleles were detected by silver nitrate according to Bassan et al. (1991). In the present case, the gel was fixed by $10 \%$ ethanol and $0.5 \%$ acetic acid for $20 \mathrm{~min}$, coloured by $6 \mathrm{mM} \mathrm{Ag} \mathrm{NO}_{3}$ for $10 \mathrm{~min}$ and fixed by $0.75 \mathrm{M}$ of $\mathrm{NaOH}$ and $0.22 \%$ of $40 \%$ formaldehyde. A digital Sony camera (DSC-P93A) was used to photograph the gels. The size of the alleles was calculated by the program Kodak EDAS-290 while the 10 bp and 50 bp DNA Ladders were used as the markers.

The number and frequency of alleles, the observed and expected heterozygosity were calculated by the GENEPOP 1.2 (Raymond and Rousset, 1995). The same software was used to calculate the Hardy-Weinberg equilibrium, the deficit or excess of heterozygosity, and the linkage disequilibrium between loci pairs were calculated by the Markov chain. The paternity was determined by the PAPA software, version 2.0 (Duchesne et al., 2002).

\section{RESULTS}

\section{Genetic diversity}

The eight loci had a total of 31 alleles, two to five alleles per locus, and their sizes ranged from 182 to $268 \mathrm{bp}$ in the loci Pme5 and Pme21, respectively (Table 1). The same alleles were detected in both groups, parents and progeny. Figure 1 show the polyacrylamide gel with the four alleles in the locus Pme14 from the parents and part of the offspring. In the parental group, the loci Pme2, Pme5 and Pme28 had deviations from Hardy-Weinberg equilibrium. The Pme2 and Pme28 had excessive heterozygosity and the values of $F_{\text {IS }}$ were -0.195 and -0.180 , respectively, while the Pme5 was deficient and the $F_{\text {IS }}$ was 0.358 . The $F_{\text {IS }}$ of 0.010 indicated significant deficiency in heterozygosity (Table 1 ).

The progeny heterozygosity of 0.563 was similar to 0.550 which was the estimate from the parental group. All the loci in the progeny had negative $F_{\text {IS }}$ (from -0.020 to -0.360), except the locus Pme4 which presented the positive $F_{\text {IS }}$ of 0.031 . However, no $F_{\text {IS }}$ was statistically different from zero which indicated neither excess nor deficiency of heterozygosity in all the loci. Therefore, the progeny had no significant deviation from the Hardy-Weinberg equilibrium (Table 1). The linkage disequilibrium occurred in the following six pairs of loci (Pme2 x Pme14, Pme2 x Pme20, Pme5 x Pme20, Pme14 x Pme28, Pme20 x Pme28, Pme21 x Pme28) but they presented different patterns of linkage disequilibrium for parents and progeny.

\section{Parental contribution to offspring production}

Only six out of nine females $\left(\mathrm{F}_{1}, \mathrm{~F}_{3}, \mathrm{~F}_{5}, \mathrm{~F}_{6}, \mathrm{~F}_{8}\right.$, and $\left.F_{9}\right)$ and six or seven out of eleven males $\left(M_{1}, M_{2}\right.$, $\mathrm{M}_{3}, \mathrm{M}_{4}, \mathrm{M}_{7} / \mathrm{M}_{8}$, and $\mathrm{M}_{9}$ ) were capable to produce the offspring and, consequently, the effective number of contributing parents $\left(N_{\mathrm{e}}\right)$ was reduced from 19.8 to 12.9 . The males number seven and eight were not discriminated by using just eight loci. The analysis of data was able to establish only $60 \%$ of the paternity and it was unable to discriminate the males three and four in $13.3 \%$ of the progeny and the females six and nine in 3.3\% of the progeny (Fig. 2). The parental contribution to offspring production was discriminated for both the genders. The highest number of offspring (Fig. 2) was produced by two males $\left(M_{7}\right.$ and $\left.M_{8}\right)$ and 
four females $\left(F_{1}, F_{3}, F_{5}\right.$, and $\left.F_{9}\right)$ which characterise the disproportional contribution to offspring production. The females were fertilised by two up to six males while the males fertilised three up to five females which characterise the multiple paternity.
All the males were capable to fertilise the females because there were neither qualitative nor quantitative restrictions (spermatic motility, spermatozoa concentration, and morphology) in the semen (Table 2).

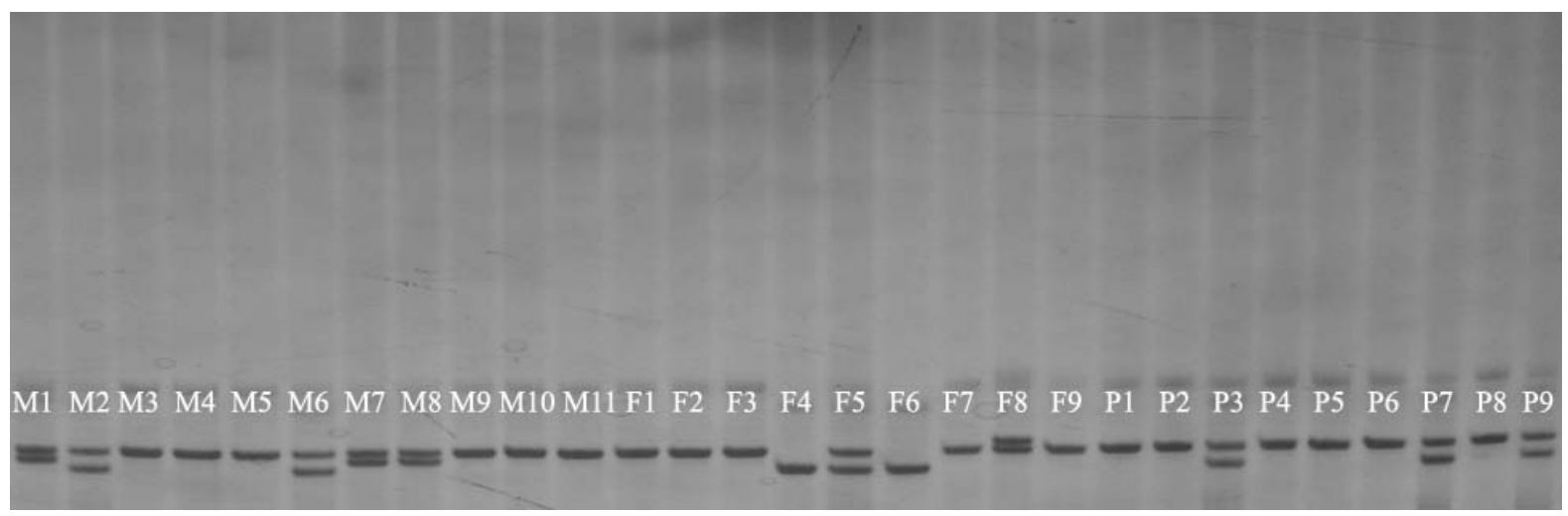

Figure 1 - Polyacrylamide gel showing four alleles in the locus Pme14 from males (M1 to M11), females (F1 to F9) and offspring (P1 to P9).

Table 1 - Number and size of alleles, observed $\left(H_{\mathrm{O}}\right)$ and expected heterozygosity $\left(H_{\mathrm{E}}\right)$, coefficient of endogamy $\left(F_{\mathrm{IS}}\right)$, and probability test for deviation from Hardy-Weinberg equilibrium (P-HW) in eight loci investigated from parents and offspring of Piaractus mesopotamicus.

\begin{tabular}{|c|c|c|c|c|c|c|c|c|c|c|}
\hline \multirow{2}{*}{ Locus } & \multirow{2}{*}{$\begin{array}{l}\text { Number } \\
\text { de alleles }\end{array}$} & \multirow{2}{*}{$\begin{array}{c}\text { Size of } \\
\text { alleles (bp) }\end{array}$} & \multicolumn{3}{|c|}{ Parents } & \multirow{2}{*}{ P-HW } & \multicolumn{3}{|c|}{ Offspring } & \multirow{2}{*}{ P-HW } \\
\hline & & & $H_{O}$ & $\boldsymbol{H}_{\mathrm{E}}$ & $F_{\mathrm{IS}}$ & & $H_{0}$ & $H_{\mathrm{E}}$ & $F_{\text {IS }}$ & \\
\hline Pme2 & 5 & $195-213$ & 0.950 & 0.799 & -0.195 & $0.001 * *$ & 0.791 & 0.759 & -0.042 & 0.281 \\
\hline Pme4 & 5 & $191-213$ & 0.900 & 0.812 & -0.112 & 0.101 & 0.744 & 0.768 & 0.031 & 0.687 \\
\hline Pme5 & 4 & $182-200$ & 0.450 & 0.695 & 0.358 & $0.002 * *$ & 0.882 & 0.658 & -0.360 & 0.233 \\
\hline Pme14 & 4 & $195-208$ & 0.350 & 0.449 & 0.225 & 0.294 & 0.490 & 0.431 & -0.138 & 0.822 \\
\hline Pme20 & 2 & 213-215 & 0.300 & 0.431 & 0.309 & 0.286 & 0.342 & 0.287 & -0.190 & 0.575 \\
\hline Pme21 & 3 & $260-268$ & 0.150 & 0.145 & -0.040 & 1.000 & 0.083 & 0.081 & -0.020 & 1.000 \\
\hline Pme28 & 5 & 209-227 & 0.900 & 0.762 & -0.180 & $0.013 *$ & 0.833 & 0.713 & -0.170 & 0.250 \\
\hline Pme32 & 3 & $242-247$ & 0.400 & 0.347 & -0.160 & 1.000 & 0.340 & 0.329 & -0.030 & 0.426 \\
\hline Means & 3,9 & - & 0.550 & 0.555 & $0.010^{* *}$ & - & 0.563 & 0.503 & -0.122 & - \\
\hline
\end{tabular}

Table 2 - Qualitative and quantitative traits of semen of Piaractus mesopotamicus in a semi-natural reproduction system.

\begin{tabular}{|c|c|c|c|c|c|}
\hline \multirow{3}{*}{ Males } & \multicolumn{5}{|c|}{ Traits } \\
\hline & \multirow{2}{*}{ Motility (\%) } & \multirow{2}{*}{$\begin{array}{c}\text { Spermatozoa concentration } \\
\left(\text { number } / \mathrm{mLx} 10^{6}\right) *\end{array}$} & \multicolumn{3}{|c|}{ Spermatozoa morphology } \\
\hline & & & Normal (\%) & Primary $(\%)$ & Secondary $(\%)$ \\
\hline 1 & 90 & 2.50 & 60 & 15 & 25 \\
\hline 2 & 50 & 2.27 & 80 & 15 & 5 \\
\hline 3 & 70 & 0.76 & 41 & 38 & 21 \\
\hline 4 & 80 & 1.00 & 75 & 19 & 6 \\
\hline 5 & 40 & 1.37 & 61 & 14 & 25 \\
\hline 6 & 60 & 0.89 & 71 & 18 & 11 \\
\hline 7 & 70 & 1.26 & 45 & 25 & 30 \\
\hline 8 & 60 & 1.59 & 56 & 21 & 23 \\
\hline 9 & 50 & 1.05 & 50 & 27 & 23 \\
\hline 10 & 70 & 0.17 & 45 & 21 & 34 \\
\hline 11 & 60 & 2.45 & 68 & 25 & 7 \\
\hline
\end{tabular}



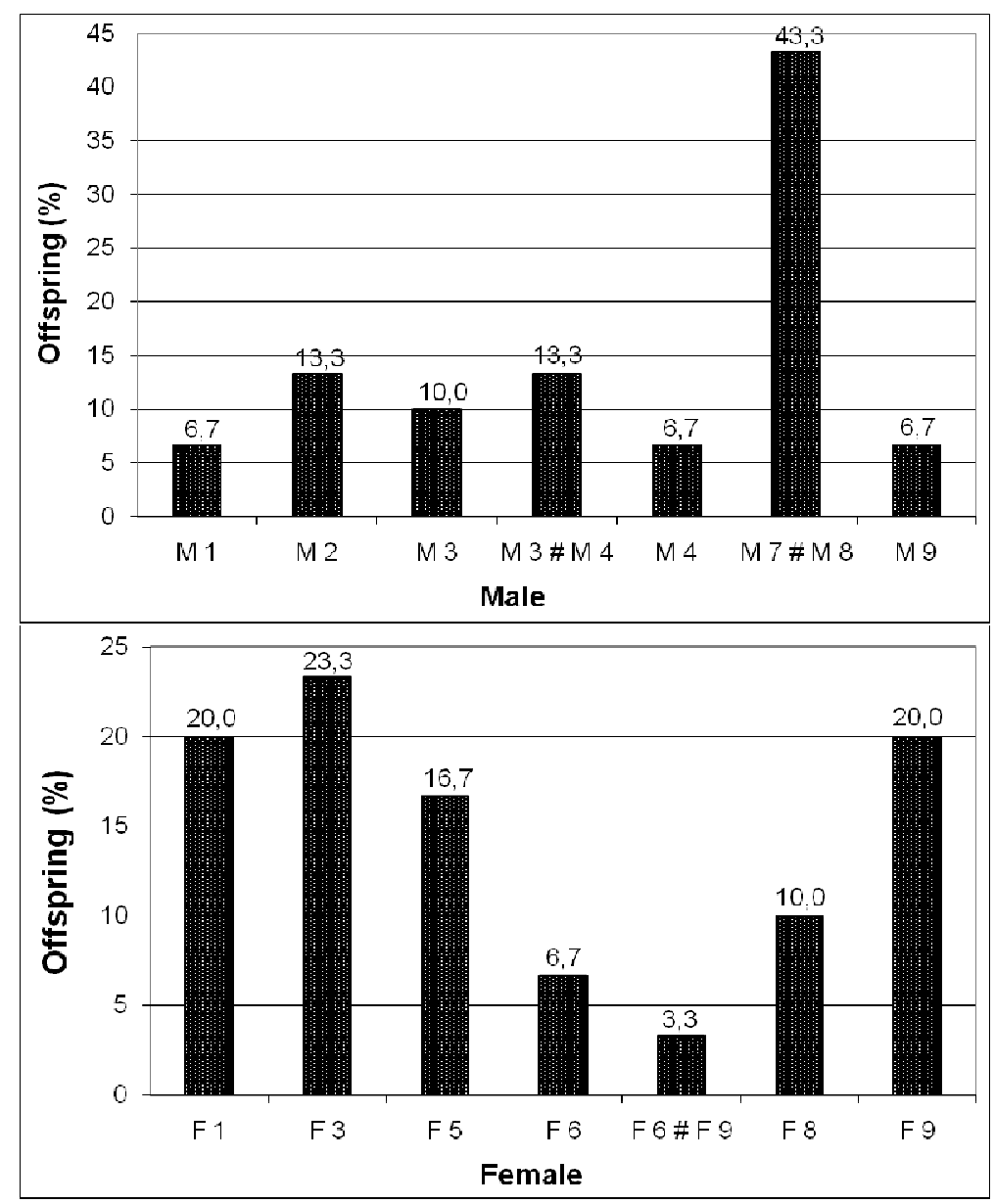

Figure 2 - Parental contribution to offspring production of Piaractus mesopotamicus in a seminatural reproduction system. The letters a and $\mathrm{b}$ indicates the contribution of the males and females, respectively.

\section{DISCUSSION}

\section{Genetic diversity}

The excessive heterozygosity in the parental fishes might be caused by the Wahlund effect, if the parents of the broodstock had been collected at different locations along the Paraná River. Accordingly, each sub-population tends to increase the homozygosity, and consequently excessive heterozygosity is detected in the parents formed in the hatchery station. On the other hand, the deficiency of heterozygosity in the locus Pme5 $\left(F_{\mathrm{IS}}=0.358\right)$ and the average in heterozygosity deficiency $\left(F_{\mathrm{IS}}=0.010\right)$ reflected the presence of endogamy. The Hardy-Weinberg equilibrium was maintained in the offspring because there was no $F_{\text {IS }}$ different of zero. Nevertheless, the present results could also be due to the random changes in the allelic frequencies because of the sampling in small population (genetic drift).

In comparison to the present experiment, the high level of heterozygosity in some loci and low level in other was found by Calcagnotto et al. (2001) who analysed eight microsatellite loci of $P$. mesopotamicus which were collected in the Pantanal Basin, in Mato Grosso, Brazil. They found low levels of heterozigose in loci Pme2 (0.852), Pme4 (0.656), Pme28 (0.643) and Pme32 (0.200) but high levels of Pme5 (0.606), Pme14 (0.667), Pme20 (0.375) and Pme 21 (0.286) in relation to the parents of the present work. Besides, they found low levels of heterozigose in loci Pme4, Pme5, Pme14, Pme28 and Pme32 in relation to the offspring of the present work. In all 
the loci, these authors detected a higher number of alleles which ranged from 10 (Pme2 and Pme28) to 7 (Pme4), except in the locus Pme20 (2 alleles), Pme21 (3 alleles) and Pme32 (3 alleles) which presented the same number alleles. The analysis of these alleles indicated a smaller genetic variability in the present work. However, the results of the present study could be affected by the founder effect, genetic drift or the different origin of the parents.

The effective number of contributing parents was reduced $\left(N_{\mathrm{e}}\right.$ from 19.8 to 12.9$)$ but it was sufficient to maintain the offspring heterozygosity of 0.563 consistent with the parental average of 0.550 . This indicated that the parental levels of genetic variability was maintained in the progeny. The loss of genetic variability could be predicted when there was significant reduction in the $N_{\mathrm{e}}$; such a loss was reported by Porta et al. (2006) who worked with the reproduction of Solea senegalensis. These authors observed that one female and two males with the $N_{\mathrm{e}}$ of 2.67 out of the total of eleven males and nine females with the $N_{\mathrm{e}}$ of 19.8 were capable to reduce the allele numbers and heterozygosity from 8.6 and 0.79 in the parents to 4.4 and 0.68 in the offspring. Such results are prone to happen (Sekino et al., 2004) due to the bottleneck effect caused by the reduction in the $N_{\mathrm{e}}$ which significantly affects the genetic variability.

The importance of higher $N_{\mathrm{e}}$ to maintain the genetic diversity was also observed by PerezEnriquez et al. (1999) who investigated Pagrus major. Accordingly, the $N_{\mathrm{e}}$ of 63.7 was capable to maintain genetic variability in the progeny (heterozygosity $=0.856$ ) similar to the parents (heterozygosity $=0.841$ ) but just $35 \%$ of those parents had effective participation in the reproduction. On the other hand, the present parental contribution of $65 \%$ was fundamental to maintain the genetic variability in the offspring (heterozygosity of 0.563 ) similar to the parental group (heterozygozity of 0.550 ) despite the low $N_{\mathrm{e}}$ (12.9). The high parental contribution was a consequence of the present protocol of reproduction which has practical effects because many national hatchery stations did not have facilities or financial support to use the large broodstocks to overcome the effects of low parental contribution.

The various patterns of disequilibrium among loci pairs either from the parents or progeny suggested no physical linkage. These results were consistent with Small et al. (2006) who reported that the disequilibrium observed in Oncorhynchus keta was not caused by the physical linkage but endogamy because such loci were independently transmitted through the generations. In the present case, further investigation on segregating population should be carried for achieving more accuracy in discriminating the physical linkage.

\section{Parental contribution to offspring production}

There was multiple paternity of $P$. Mesopotamicus in the semi-natural system of reproduction but no contribution of the males five, six, ten, and eleven. However, there were neither qualitative nor quantitative restrictions in the semen collected from such males which might have affected their contribution to offspring production. These males had satisfactory conditions for mating (Table 4). However, Sekino et al. (2003) observed that the semen quality might have affected the reproduction of Paralichthys olivaceus because just one out of six males was capable to produce 99\% of offspring. Campton (2004) also suggested that semen quality was capable to affect the progeny of Salmo salar.

The disproportional contribution of the males to the offspring production (Fig. 2) was not related to the capacity of fertilisation because males like the number one, which had incipient participation in the offspring production, had similar qualitative and quantitative semen parameters to the males number seven and eight. Similarly, the males number eleven, five, and ten had no participation (Table 4). If the males seven and eight had had similar contribution to the $43.3 \%$ of the offspring (Fig. 2), the individual participation would have been much more close to other males which had participation in the range between $6.7 \%$ and $13.3 \%$. On the other hand, the disproportional contribution of the females was lower than the males. In this case, females number six and eight had 3.3 and $10.0 \%$ of contribution while females number one, three, five, and nine had participation in the range between 16.7 and $23.3 \%$.

The group hierarchy and consequently the mating system are affected by the stress (Tuyttens and MacDonald, 2000) which may explain the disproportional participation. The low parental determination by investigating just eight loci (60\%) could be another factor affecting the accuracy of the genetic contribution to the offspring. Apparently, the disproportional contribution did not indicate the parental 
dominance in the semi-natural system of reproduction. Similarly, the incipient know-how about the reproductive performance of $P$. mesopotamicus in such a system indicated the needs of additional studies for detecting the hierarchal dominance.

\section{CONCLUSION}

There was no evidence by the microsatellite marker of losses in the genetic variability of the progenies of P. mesopotamicus in the semi-natural system of the reproduction. There was multiple paternity with a reasonable number of contributing parents to the production of the offspring. The use of microsatellite markers was effective in monitoring the genetic variability which was fundamental for the management decisions in stock enhancement programmes.

\section{ACKNOWLEDGEMENTS}

The authors thank Duke Energy International for the access facilities which supported this study and the Universidade Estadual de Maringá for technical and scientific counselling.

\section{RESUMO}

O objetivo deste trabalho foi avaliar a diversidade genética e a contribuição parental de Piaractus mesopotamicus na produção de descendência no sistema seminatural de reprodução. Vinte peixes parentais (onze machos e nove fêmeas) e o total de 100 larvas foram avaliados por meio do marcador microssátelite. Os parentais e a progênie tiveram trinta e um alelos e heterozigosidade de 0,550 e 0,563 , respectivamente. As fêmeas foram fertilizadas por dois até seis machos enquanto machos fertilizaram três até cinco fêmeas. A contribuição de fêmeas e machos para a descendência seja 66,6 e 58,0\%, respectivamente. Tais resultados não indicam diminuição da variabilidade genética na progênie e os parentais apresentaram paternidade múltipla e razoável contribuição à produção de descendência.

\section{REFERENCES}

Agência Estadual de Notícias (2007), Soltura de peixes nos rios do Paraná. Disp. In: <http://www.agenciadenoticias.pr.gov.br>. Access on: 18 Ago. 2007.

Agostinho, A.A.; Gomes, L.C.; Suzuki, H.I. and Júlio JR., H.F. (2003), Migratory fish of upper Paraná River basin, Brazil. In: Carolsfeld, J.; Harvey, B.; Baer, A. and Ross, C. (Eds.), Migratory fishes of South America. Biology Social Importance and Conservation Status, Victoria, pp. 19-99.

Agostinho, A.A.; Thomaz, S.M. and Gomes, L.C. (2005), Conservação da biodiversidade em águas continentais do Brasil. Megadiversidade, 1, 70-78.

Aljanabi, S.M. and Martinez, I. (1997), Universal and rapid salt-extraction of high quality genomic DNA for PCR-based techniques. Nucl. Acids Res., 25, 4692-4693.

Barroso, R.M.; Hilsdorf, A.W.S.; Moreira, H.L.M.; Cabello, P.H. and Traub-Cseko, Y. (2005), Genetic diversity of wild and cultured populations of Brycon opalinus (Cuvier, 1819) (Characiforme, Characidae, Bryconiae) using microsatellites. Aquaculture, 247, 51-65.

Bassam, B.J.; Caetano-Anollés, G. and Gresshoff, P.M. (1991), Fast and sensitive silver staining of DNA in polyacrylamide gels. Anal. Biochem., 196, 80-83.

Billard, R.; Cosson, J.; Crim, L.W. and Suquet, M. (1995), Broodstock management and seed qualityGeneral considerations. In: Bromage, N. and Roberts, R.J. (Eds.), Broodstock management and egg larval quality. Blackwell Science, Oxford, pp. 1-24.

Britto, S.G.C.; Sirol, R.N.; Vianna, N.C.; Jardim, M.S.; Santos, J.C. and Pelisari, E. (2003), Peixes do rio Paranapanema. Duke Energy Internacional Geração Paranapanema, São Paulo, 112 pp.

Calcagnotto, D.; Russello, M. and Desalle, R. (2001), Isolation and characterization of microsatellite loci In Piaractus mesopotamicus and their applicability in other Serrasalminae fish. Mol. Ecol. Notes, 1, 245247.

Campton, D.C. (2004), Sperm competition in salmon hatcheries: the need to institutionalize genetically benign spawning protocols. Trans. Am. Fish. Soc., 133, 1277-1289.

Duchesne, P.; Godbout, M.H. and Bernatchez, L. (2002), PAPA (package for the analysis of parental allocation): a computer program for simulated and real parental allocation. Mol. Ecol. Notes, 2, 191-193.

Hatanaka, T.; Henrique-Silva, F. and Galetti, JR., P.M. (2006), Population substructuring in a migratory freshwater fish Prochilodus argenteus (Characiformes, Prochilodontidae) from the São Francisco River. Genetica, 126, 513-517. 
Liu, Y.; Chen, S. and Li, B. (2005), Assessing the genetic structure of three Japanese flounder (Paralichthys olivaceus) stocks by microsatellite markers. Aquaculture, 243, 103-111.

Ortega-Villaizán Romo, M.M.; Aritaki, M. and Taniguchi, N. (2006), Pedigree analysis of recaptured fish in the stock enhancement program of spotted halibut Verasper variegatus. Fish. Sci., 72, 48-52.

Perez-Enriquez, R.; Takagi, M. and Taniguchi, N. (1999), Genetic variability and pedigree tracing of a hatchery-reared stock of red sea bream (Pagrus major) used for stock enhancement, based on microsatellite DNA markers. Aquaculture, 173, 413423.

Porta, J.; Porta, J.M.; Matínez-Rodríguez, G. and Alvarez, M.C. (2006), Development of a microsatellite multiplex PCR for Senegalese sole (Solea senegalensis) and its application to broodstock management. Aquaculture, 256, 159-166.

Ramella, M.S.; Kroth, M.A.; Meurer, S.; Nuñer, A.P.O.; Zaniboni-Filho, E. and Arisi, A.C.M. (2006), Genetic Variability in Four Fish Species (Pimelodus maculatus, Prochilodus lineatus, Salminus brasiliensis and Steindachneridion scripta) from Uruguay River Basin. Braz. Arch. Biol. Technol., 49, p.589-598, 2006.

Raymond, M. and Rousset, F. (1995), GENEPOP (version 1.2): population genetics software for exact tests and ecumenicism. J. Heredity, 86, 248-249.

Sekino, M.; Saitoh, K.; Yamada, T.; Kumagai, A.; Hara, M. and Yamashita, Y. (2003), Microsatellitebased pedigree tracing in a Japanese flounder Paralichthys olivaceus hatchery strain: implications for hatchery management related to stock enhancement program. Aquaculture, 221, 255-263.

Sekino, M.; Sugaya, T.; Hara, M. and Taniguchi, N. (2004), Relatedness inferred from microsatellite genotypes as a tool for broodstock management of Japanese flounder Paralichthys olivaceus. Aquaculture, 233, 163-172.

Sirol, R.N. and Britto, S.G. (2006), Conservação e manejo da ictiofauna: repovoamento. In: Nogueira, M.G.; Henry, R. and Jorcin, A. (Eds.), Ecologia de reservatórios: impactos potenciais, ações de manejo e sistemas em cascatas. RiMA, São Carlos, pp. 275284.
Small, M.P.; Frye, A.E.; Von Bargen, J.F. and Young, S.F. (2006), Genetic structure of chum salmon (Oncorhynchus keta) populations in the lower Columbia River: are chum salmon in Cascade tributaries remnant populations? Cons. Genet., 7, 6578.

Sonstebo, J.H.; Borgstrom, R. and Heun, M. (2007), Genetic structure of brown trout (Salmo trutta L.) from the Hardangervidda mountain plateau (Norway) analyzed by microsatellite DNA: a basis for conservation guidelines. Cons. Genet., 8, 33-44.

Streit Jr., D.P.; Moraes, G.V.; Ribeiro, R.P.; Povh, J.A.; Souza, E.D. and Oliveira, C.A.L. (2004), Avaliação de diferentes técnicas para coloração de sêmen de peixes. Arq. ciên. vet. zool., 7, 157-162.

Tejerina-Garro, F.L.; Maldonado, M.; Ibañez, C.; Pont, D.; Roset, N. and Oberdorff, T. (2005), Effects of natural and anthropogenic environmental changes on riverine fish assemblages: a framework for ecological assessment of Rivers. Braz. Arch. Biol. Technol., 48, 91-108.

Tuyttens, F.A.M. and Macdonald, D.W. (2000), Consequences of social perturbation for wildlife management and conservation. In: Gosling, M.L. and Sutherland, W.J. (Eds.), Behaviour and Conservation. Cambridge University Press, Cambridge, pp. 315329.

Zaniboni-Filho, E. and Nuñer, A.P.O. (2004), Fisiologia da reprodução e propagação artificial dos peixes. In: Cyrino, J.E.P.; Urbinati, E.C.; Fracalossi, D.M. and Castagnolli, N. (Eds.), Tópicos especiais em piscicultura de água doce tropical intensiva. TecArt, São Paulo, pp. 45-73.
Received: November 08, 2007; Revised: March13, 2008; Accepted: August 04, 2009 